\title{
THE MARITAL AND PHYSICIAN PRIVILEGES- A REPRINT OF A LETTER TO A CONGRESSMAN
}

\author{
Charles L. Black, JR.*
}

\section{Author's Introductory Note}

I am much disturbed by the treatment given to "privilege," in Moore and Bendix, "Congress, Evidence and Rulemaking." 1 My disturbance centers mainly on their treatment of the marital and physician privileges.

As to the first of these (the marital privilege) I am surprised at the seeming suggestion ${ }^{2}$ that the proposed Court Rules advocated by Moore and Bendix (and rejected by Congress) pretty much supported the husband-wife privilege. Actually, that privilege would have been cut to the bone and into the bone by the Court Rules, leaving only the most meager protection to the privacy of this most intimate human relation.

But it is not such minor imaccuracies, or possible inaccuracies, that bother me most. I am most bothered by the hidden major premises: (1) that development of evidence in litigation outweighs virtually every other interest in life, particularly the human interest in privacy; and (2) even more, that all this is mostly a matter of technicalities about Erie Railroad v. Tompkins, and not a matter of the quality of life and of its essential privacies.

In the following letter to Congressman Hungate, I tried to combat these ideas. I think the letter may be worth reprinting ${ }^{3}$ now that some of the dust is beginning to settle. Congress has enacted a set of evidentiary rules incorporatimg the common law of testimonial privilege, ${ }^{4}$ but at least one state has adopted the originally proposed rules of privilege outright and in many others it is possible that those proposals will have affected the common law in less obvious ways.

* B.A. 1935, M.A. 1938, Umiversity of Texas; LL.B. 1943, Yale; Member of New York Bar; Henry R. Luce Professor of Jurisprudence, Yale Law School.

1. 84 YAlE L.J. 9, 19-27 (1974).

2. Id. at $20 \&$ n. 50 .

3. Ed. Note: This letter was originally printed in Hearings on Proposed Rules of Evidence Before the Special Subcomm. on Reform of Federal Criminal Laws of the House Comm. on the Judiciary, 93d Cong., 1st Sess., Ser. 2, at 240 (1973).

4. Ed. Note: Pub. L. No. 93-595, Rule 501, 43 U.S.I.W. 137 (Jan. 14, 1975). 
February 5, 1973

Honorable William L. Hungate

Chairman, Special Subcommittee on

Reform of Federal Criminal Laws

Committee on the Judiciary

U.S. House of Representatives

Washington, D.C. $\quad 20515$

My dear Congressman Hungate:

I have received a letter from Mr. Hoffman [Committee Counsel] of 16 January, inviting my further comments on the proposed Rules of Evidence for federal courts. In the hope that this letter will not be too late for inclusion in the Record of Hearings, I shall soinewhat amplify the thoughts sketched in my letter of 9 January to Senator Ervin, referred by him to your Committee.

My primary interest is in the constitutional position. I shall first outline the nature of my general objection from the constitutional point of view, and then say enough about the merits of a few particular rules to connect them with the general constitutional difficulty which I foresee.

In outline, the trouble is: (1) that some of these Rules are subject to grave constitutional objection, either as a whole or in possible applications; (2) that only the Supreme Court can or should decide finally on the constitutional validity of each Rule, and of its only partly foreseeable applications; (3) that the Court cannot adequately have considered these hard and complex constitutional questions in the process of approving this long set of Rules, and does not claim to have done so; but (4) that the Court, if the Rules are now promulgated, will undoubtedly have compromised its position with respect to the full and judicially regular consideration of these issues, one by one, after the manner of courts; in no other context would it be regarded as even debatable whether the promulgator of rules should afterwards be the last resort judge of their constitutionality, as the constitutional issues arise in cases. (Incidentally, the lower courts are put in an even more difficult position in the same connection.)

The inference from this sequence of thought is that, if Congress allows these Rules to become law, there will never have taken place and never can take place any judicial consideration of their constitutionality which is both plenary and nncompromised by prior commitment. Here we have to do not with an arid philosophic question of "separation of powers," but with a real and substantial confusion of function at the very highest level, the level of constitutional decision. 
These points could be lengthily elaborated, but such elaboration would amount only to an invocation, one by one, of the soundly settled principles of constitutional adjudication (the real controversy, the parties' relation of exigent adversity, the availability to the Court of help froin committed advocacy, the consideration of issues of law in a setting of concrete fact, and so on) and one of the oldest principles of judicial judgment in general - that the court not have committed or semi-committed itself before the case is heard. Such elaboration is unnecessary when one writes for a Committee of lawyers. I cannot think that any lawyer could, on full reflection, be satisfied with this way of dealing with great constitutional issues.

I am fully aware that these objections apply in principle to every case of rule-making by the Court. In every Rule of Procedure a dueprocess question may lurk. I have to confess, moreover, that I myself served for ten years on the Advisory Committee on Admiralty Rules without bringing these objections into focus in my own mind. But I think it natural, if regrettable, that objections of this sort should first be seen clearly when something miportant is visibly at hazard; it is, indeed, the very weakness in human perception that underlies many of the canons (just rehearsed) concerning the conditions of sound constitutional adjudication.

There is something very important at stake in these Rules of Evidence. At several points, they give major aid and comfort to that diminishment of human privacy which is one of the greater evils of our time, thus raising not only prime questions of value, but also questions of constitutional law which could never have been dismissed as trivial, but which are even more plainly substantial in the hight of such recent decisions as Griswold v. Connecticut, 381 U.S. 479 (1965). I refer, of course, to the treatment the Rules give to the inarital and to the physician-patient privileges.

I am not an expert on the law of evidence. The short discussion which follows is not meant to be exhaustive, and cannot be learned, but is meant only as a concretization of the clain that real and substantial constitutional issues are being settled (or at least severely prejudiced) in these Rules, in a maimer fundamentally wrong-the claim, in other words, that the progression of thought in my numbered points above generates an objection not to mere procedural impropriety as such but to the procedurally wrong handling of exceedingly important interests and issues.

(Let me add that I neither know nor care how far the privacies here at stake have already been invaded by state rules of evidence. 
To any such matter, two objections are decisive, since they together cover the whole ground. First, many state rules of evidence (even if inveterate and certainly if innovatory) may themselves be seriously questioned as violative of the national Constitution, and of the values it embodies; the argument from them to federal constitutionality or to desirability is a bootstraps argument, for it assumes their validity, as against just the same objections as those which would be levied against the federal material if it be adopted. Secondly, Federal Rules are leadership rules, and ought to lead in the right direction, which to me would be in the direction of greater rather than less protection of personal privacy; this leadership becomes the more rather than the less important if the States are now going in the wrong direction.)

Let me first consider the near-elimination of the marital-confidentiality privilege (Rule 505). ${ }^{5}$ There remains a narrow privilege in proceedings where one spouse is a criminal defendant. Aside from this, the meaning of the Rule (made entirely clear in the Advisory Committee's comments) is that, however intimate, however private, however embarrassing may be a disclosure by one spouse to another, or some fact discovered, within the privacies of marriage, by one spouse about another, that disclosure or fact can be wrung from the spouse under penalty of being held in contempt of court, if it is thought barely relevant to the issues in anybody's lawsuit for breach of a contract to sell a carload of apples. It ought to be enough to say of such a rule that it could easily-even often-force any decent person-anybody any of us would want to associate with-either to lie or to go to jail. No rule can be good that has that consequence-that compels the decent and honorable to evade or to disobey it. It seems clear to me that this Rule trenches on the area of marital privacy so staunchly defended by the Supreme Court, and especially by the late Mr. Justice Harlan's concurrence, in Griswold v. Connecticut, supra; certainly it is arguable that it does so. Even if Griswold had never been decided, it would be an entirely viable contention that the "scheme of ordered liberty," sanctioned in much earlier cases, forbade this nearly complete destruction of the privacy of marriage, in the interest of the conduct of ordinary litigation.

The reasonableness of this Rule may be tested by sampling the quality of some of the arguments tendered by the Advisory Committee

5. Ed. Note: The Supreme Court of New Mexico has adopted this definition of the marital privilege. 4 N.M. STAT. ANN. 20-4-505 (Supp. 1973). In Wisconsin, however, the court specifically foresaw this near-elimination of privacy and modified Rule 505 to protect "any private communication by one to the other made during their marriage." 20L WIS. STAT. ANN. 905.05 (1974). 
in its defense. The marital privilege is downgraded, for example, by contrasting the marriage relation with other relations to which privilege is accorded, on the ground forsooth, that those other relations are "essentially and almost exclusively verbal in nature, quite unlike marriage." [Emphasis supplied.] Does this mean, can it be meant, that the marriage relation is entitled to the less protection because its parties sleep together, found and maintain a home together, raise children together, besides talking to each other? But if not that, what is meant?

It is said, further, that these other, favored relations "have as one party a professional person who can be expected to inform the other person of the existence of the privilege." What is the sequence of thought here? Why should the confidentiality of a relation be favored simply because knowledge of this confidential character is more likely to come to the parties? Is it so obvious that the effect of prior knowledge on conduct is the one and only reason for respecting the privacies of human life? Is it not the intrinsically private character of the relation, and the reciprocal indecency of invading that privacy, rather than the parties' knowledge of the law of evidence, that chiefly justifies confidentiality? I really cannot see the firm outline of a thought here. I would understand what was meant if it were said that the confidentiality of some relationship ought not to be protected, on the ground that warning of this non-confidential character could easily be communicated to the parties. I suspect that somebody has just turned this intelligible thought around verbally, without noticing that it doesn't work in reverse. If there is in any sense a substance in the argument as proffered, the solution would be to maintain the marital privilege, and to disseminate more widely, knowledge of its existence.

Very plainly, the question of the obnoxiousness of this Rule to objections rooted in the constitutional law of privacy is a grave question; there are few graver. Now is not the time to argue this question in full. But now is the time to decide that if it must arise, it ought to come before a Court which has not already decided it, in effect, by issumg this Rule, but which does not so much as clain to have issued this Rule after full judicial consideration of its four-square constitutionality-a clain which would in any case be a clain of the impossible, since the conditions for proper judicial consideration of issues of constitutional law exist only in real law-suits.

Hardly less grave is the invasion of central human privacy involved in the root-and-branch abolition of the physician-patient privilege. ${ }^{\circ}$

6. Ed. Note: The rules proposed by the Supreme Court and adopted by New Mex- 
The question here is not only whether people might be discouraged from making full communication to physicians, though it seems flatly impossible that this would not sometimes happen-a consideration which would in itself be enough to make incomprehensible the absolute subordimation of this privacy interest to any trivial interest arising in hitigation. But evaluation of a rule like this entails not only a guess as to what conduct it will motivate, but also an estimate of its intrinsic decency. All of us would consider it imdecent for a doctor, in the course, say, of a television interview, or even in a textbook, to tell all he knows, naming names, about patients who have been treated by him. Why does this judgment of decency altogether vanish from sight, sink to absolute zero, as soon as somebody files any kind of a nondemurrable complaimt in a federal court? Here, again, can a rule be a good one when the ethical doctor must violate it, or hedge, or evade?

In Rochin v. California, 342 U.S. 165 (1952), the late Mr. Justice Frankfurter, for the Court, condemned as utterly indecent the forced punping of a man's stomach to get criminal evidence. Does not the forced revealing of every medical and personal fact, stomach contents and all, learned by the doctor of a person not even suspected of anything, just to serve the convemience of any litigant, partake at least a little of the same indecency? Do not these and many other considerations lead to the discernment of constitutional as well as of policy issues here? If so, then the sanie remarks as those made above apply to the posture in which those constitutional issues are put by the promulgation of these Rules.

(It should be noted that, in an inverted way, the Advisory Committee recognizes that its abolition of this privilege is retrograde, since many states have created it by statute. These statutes often contain exceptions; the reasonableness of these-and some do seein reasonable -is not in issue here.)

I must go on to note how strangely inconsistent these Rules are with respect to the matter of privilege. The imconsistencies are so remarkable as to raise constitutional doubts on the score of arbitrariness.

First, though no privilege whatever is to inhere in the physicianpatient relation as such, Rule 504 extends a fairly anple privilege to

ico, 4 N.M. STaT. ANN. 20-4-504 (1973), protect only those statements made by a patient to his doctor about his emotional or mental condition. The privilege is properly labeled the psychotherapist privilege. The Supreme Court of Wisconsin, anticipating the problems involved in limiting the physician privilege, extended protection to communications by the patient about his physical condition as well. 20L WIS. STAT. ANN. 905.04 (1974). 
communications of patient to psychotherapist. If a man, consulting a heart specialist, reveals in the course of his case-history interview, that he has had gonorrhea, then the cardiologist must divulge this in court, whenever and wherever any hitigant needs the revelation. If a man under therapy for psychoneurosis reveals that his having had gonorrhea has filled him with guilt, that communication is protected. This is preposterous. It is a case of the tail ceasing to wag the dog, and continuing to wag in place after the dog has gone away. Psychotherapy is privileged, and ought to be amply privileged, exactly because it is a kind of medicine, and a human being ought to be able to consult any hind of a doctor without by that act, or by the necessities of commumcation consequent on that act, rendering himself vulnerable to being stripped to and below the skin in public. There is no ground whatever for singling out psychotherapy for special treatment. Any patient has to reveal lis condition, verbally or otherwise, $\mathrm{m}$ order to be treated effectively. Moreover, for what it is worth, most competent doctors of all sonts very often concern themselves with emotional conditions.

Another strange anomaly, at least in the foothills of due-process arbitrariness, is found in the according of a privilege to "Communications to Clergymen" (Rule 506) while marital confidentiality is abolished. The one and only distinction here is the almost ludicrously counterpersuasive one discussed above-that confession and its analogues, unlike marriage are "purely verbal." Brushing aside this nonground of distinction, one is bound to see "establishment of religion" issues, as well as issues of capricious arbitrariness, in the Rules' preferring the occasional or even casual "spiritual" relationship to the deep spiritual tie between husband and wife.

I have saved to last the lawyer-client privilege (Rule 503). You and $I$ are both lawyers, and we understand the necessity for this privilege. But, as a lawyer, I own I find it embarrassing that a group of lawyers, having so summarily dealt with the privacies of marriage and of medicine, proceed, without any satisfactory explanation of the vast difference, to shield our own profession so amply. I wonder what hind of Rules we would have gotten if the doctors had drawn thein.

One final clarification: I am not against any of these privileges. I believe in the attorney, clergyman, and psychotherapist privileges in all their width; if anything, I would widen thein, for I beheve many human interests are inore important than the conduct of whatever litigation may from time to time arise. I am concerned only with the entirely unwarranted contrast between the treatment of these and the treatment of what are perhaps the most private and the second most 
private relations in life-marriage, and the relation of doctor to patient. If these central citadels fall, then, a fortiori, little of human privacy has warrant to claim protection.

(I have not discussed the "trade secret" privilege (Rule 508); its juxtaposition with the treatment given marriage sounds a rather sordid note. The "state secrets" privilege (Rule 509) raises issues rather remote from my present central point.)

At a time, then, when constitutional law is reaching out more and more to protect the privacies of men and women, these privilege Rules are astonishingly regressive, and raise serious constitutional issues. After all is said, my contention in chief is that these constitutional issues, if they have to come to court, ought to come there utterly and visibly unprejudiced-and that the lower courts (where in practice, many such questions will be resolved, at least for a long interim) not be or seem to be bound by the prior Supreme Court sanction which these Rules carry. These privilege Rules present a clear case in which scrupulous separation of powers is of the most solemn practical moment. If, in times like these, it is to be determined that the central human privacies are to be further weakened by rules of evidence in the federal courts, then let that determination be made, in full fact as well as in tenuous theory, by the Congress-so that the Supreme Court, when it decides whether the Constitution permits such weakening, may write on an absolutely clean slate.

That result, plainly a sound one, can now only be attained by Congress' rejecting these Rules, and I urge upon your Committee that it recommend that this be done. ${ }^{7}$

I hope this letter can be made a part of the Record of Hearings.

/s/Charles L. Black, Jr.

Luce Professor of Jurisprudence

7. Ed. Note: Congress agreed with Professor Black's recommendation. See note 4 supra and accompanying text. 